\title{
The effect Mat Pilates practice on muscle mass in elderly women
}

\author{
Efeito da prática do Pilates Solo na massa muscular de mulheres idosas
}

Leliz Cristina Sampaio Queiroz ${ }^{1}$, Sonia Maria Marques Gomes Bertolini ${ }^{1}$, Rose Mari Bennemann ${ }^{1}$, Eraldo Schunk Silva $^{2}$

Objective: to verify that the Mat Pilates practice increases muscle mass in elderly women. Methods: quasiexperimental study with primary data collection and with a convenience sample. The muscle mass of 43 elderly was evaluated for 11 weeks, by calculating the arm muscle area, before and after the intervention. Results: statistically significant difference was observed $(\mathrm{p}<0.002)$ between the average value of the arm muscle area, before $\left(35.56 \mathrm{~cm}^{2}\right)$ and after the exercises $\left(42.72 \mathrm{~cm}^{2}\right)$. Conclusion: mat Pilates program generates positive effect on increasing the muscle mass of elderly.

Descriptors: Aged; Muscle, Skeletal; Exercise Movement Techniques; Nutritional Status.

Objetivo: verificar se a prática de Pilates Solo aumenta a massa muscular de mulheres idosas. Métodos: estudo quase-experimental, com coleta de dados primários e com amostra de conveniência. Avaliou-se a massa muscular de 43 idosas por 11 semanas, por meio do cálculo da área muscular do braço, antes e depois da intervenção. Resultados: foi verificada diferença estatisticamente significativa $(p<0,002)$ entre o valor da média da área muscular do braço, antes $\left(35,56 \mathrm{~cm}^{2}\right)$ e após a prática dos exercícios $\left(42,72 \mathrm{~cm}^{2}\right)$. Conclusão: o programa de Pilates aplicado no solo gera efeito positivo no aumento da massa muscular de idosas.

Descritores: Idoso; Músculo Esquelético; Técnicas de Exercício e de Movimento; Estado Nutricional.

${ }^{1}$ Centro Universitário de Maringá. Maringá, PR, Brazil.

${ }^{2}$ Universidade Estadual de Maringá. Maringá, PR, Brazil. 


\section{Introduction}

In Brazil, the elderly population has doubled in the last 20 years, ranking in 2015, the seventh world position in number of elderly. The expectation is that by 2025 there will be about 32 million elderly people, representing $14.0 \%$ of the population. Not just increase the number of years lived, it is necessary to invest so that the increase in life expectancy is accompanied by improvements in living conditions, meaning that people can enjoy an active and healthy old age ${ }^{(1-2)}$.

The aging process can leave the elderly more susceptible to functional disabilities, in view of the loss of muscle mass, although it is natural, causes decreased muscle strength, bringing difficulties in daily routine tasks of the elderly ${ }^{(2-3)}$.

In addition, sedentary lifestyle, often observed in these individuals, combined with poor eating habits can influence and have serious consequences for the quality of life, such as dyslipidemia, hypertension, high cholesterol, obesity, malnutrition, among others ${ }^{(3)}$.

During the aging, the loss of muscle mass, with consequent decrease in muscle strength, is evident from the sixth decade of life. This process generally called sarcopenia is characterized by progressive loss of muscle mass, natural and inevitable being considered in all humans ${ }^{(4-7)}$.

Sarcopenia is due to the decrease in hormone levels, the decrease in protein synthesis and remodeling of the motor unit and especially the sedentary lifestyle. The musculature is responsible for the independence and autonomy of the human being. The higher the volume of muscle mass, the greater strength. However, when muscle strength decreases postural deviations may occur, difficulties in locomotion, pain and even overloads of the heart ${ }^{(3-4,8)}$.

The practice of regular physical activity can benefit the body in all respects, both in skeletal muscle and in physical health as maintaining independence for longer, improving the quality of life thus ensuring successful aging $(4,8)$.
Nevertheless, not all people who get motivation or enjoy activities in gyms. The number of elderly who participate in physical activity programs is lower than expected, despite the incentives of health agencies ${ }^{(9)}$.

The Pilates method, created by German Joseph Pilates Humbertus during World War $\mathrm{I}^{(10)}$, has as main objective the strengthening of the abdominal and pelvic muscles. These muscles, including the iliopsoas, lumbosacral region, pelvic floor and quadriceps, are widely used to stabilize the torso, providing thereby improvement of the pain condition, spinal stabilization, and posture maintenance also preventing damage $\mathrm{e}^{(10-11)}$.

The Pilates method is divided into two types of sessions: on the floor (also called The Mat) and the apparatus (chair, Reformer, Wall, trapeze). The exercises performed on the floor use our own body weight and gravity as resistance factors, and accessories can also be added like Swiss balls, rubber bands, erasers and dumbbells ${ }^{(12)}$.

With aging, the body tends to become more dependent, requiring the maintenance of autonomy and encouragement to perform physical exercises. The Pilates method is also recommended as a great activity program for the elderly, because it works the body globally, realigns the muscles, increases neuromuscular control, performance, coordination and mobility. And so it improves balance, muscle tone and correct posture, and increases the independence to perform daily activities ${ }^{(12-13)}$.

Given the importance of muscle strength in maintaining balance in walking ability, in preventing the occurrence of joint pain and therefore in maintaining a healthy life in old age, this study aimed at verifying if the Mat Pilates practice increases muscle mass in elderly women.

\section{Methods}

It is a quasi-experimental study, of the before and after type, with primary data collection and with a convenience sample. Elderly with 60 or more years of 
age were invited to participate; they attend a Cultural and Social Center, Living Services for the Elderly, in Maringá-PR, Brazil.

The institution offers the elderly the different community programs that focus on physical, artistic and cultural, educational and religious activities. In addition to this, there are other educational and cultural activities that contribute to self-knowledge and self-care.

At first, a meeting was held with the director of the institution for clarification and authorization of the project. Then another meeting was scheduled with elderly interested in the activity to define the dates of the evaluations and the dates of practical classes. All elderly women who agreed to participate in the study who had a medical certificate to practice physical exercises and time availability to participate in the research were included.

Male subjects and elderly of male gender with motor/physical problems that prevented physical exercises were excluded. The elderly women who agreed to participate signed a free and informed consent form and were informed in detail about the procedures used.

The evaluation of muscle mass was held by the arm muscle area (AMA), before and after the intervention. The arm muscle area was calculated by this equation:

\section{Women: AMA $\left(\mathrm{cm}^{2}\right)=[\mathrm{AC}(\mathrm{cm})-\mathrm{p} \times \mathrm{DTST}(\mathrm{mm}) \div 10]^{2}-6,5 \mathrm{~cm}$} $4 \mathrm{p}$

The measurement of the arm circumference (AC) was made with a measuring tape, the Sanny ${ }^{\circledR}$ brand, at first with the elderly standing, trunk aligned with the legs, arms flexed at $90^{\circ}$. The average point was measured between the acromion and the olecranon, whose measurement is made at arm's length at the midpoint, obtained initially the tape surrounding the arm without compressing. Three consecutive measurements were performed, allowing a difference among them of no more than $0.5 \mathrm{~cm}$, and their average was used.

The triceps skinfold (TSF) was measured with the use of the Lange device, with pressure of $10 \mathrm{~g} /$ $\mathrm{mm}^{2}$. The elderly was positioned standing, trunk aligned with the legs, arms outstretched next to the body. The fold thickness was measured in the right arm, with the arm extended to the side of the trunk, at the midpoint described above. The measurement was performed three times, allowing a difference between them of at most $0.5 \mathrm{~mm}$, using the average.

For analysis of the arm muscle area, before and after the intervention, values were used presented in percentiles according to gender and age ${ }^{(14)}$.

Based on the values of muscle area of each arm elderly, the elderly were classified as follows: inadequate muscle mass when presented muscle area values of the arm below the percentile of the reference population and age; proper muscle mass when presented muscle area values of the arm larger or equals to the percentile of the reference population, according to sex and age.

The collection of demographic data was conducted through a questionnaire consisting of personal identification, occupation and date of birth. The instrument was divided into two parts: characterization and anthropometric data. The Mat Pilates classes were practiced for three months, three times a week, 40 minutes a day. The exercises were aimed at beginners, since all older had never practiced the method. The classes were progressing gradually with or without the use of some accessories such as balls, elastic and rolling pin.

At first auxiliary materials were not used in class. In the second month, alternative materials were used and the intensity of the classes was increased gradually according to the evolution of the elderly. Last month, the intensity of the classes continued to increase gradually, respecting the evolution of the elderly. The schedule is shown in Figure 1. 


\begin{tabular}{|c|c|l|c|l|l|}
\hline $\begin{array}{c}\text { Period } \\
\text { (months) }\end{array}$ & Class time (min.) & \multicolumn{1}{|c|}{ Intensity } & $\begin{array}{l}\text { Frequency (times } \\
\text { per week) }\end{array}$ & \multicolumn{1}{c|}{ Repetitions } & \multicolumn{1}{c|}{ Exercises } \\
\hline $1^{\text {st }}$ & 40 & $\begin{array}{l}\text { Light; } \\
\text { Without the aid of alternative } \\
\text { materials. }\end{array}$ & $\begin{array}{l}\text { Stretching; } \\
\text { Breath learning; } \\
\text { Movement learning; } \\
\text { The exercises. }\end{array}$ \\
\hline $2^{\text {nd }}$ & 40 & $\begin{array}{l}\text { Moderate; } \\
\text { Exercises with the aid of balls } \\
\text { and roller pins. }\end{array}$ & 3 & $\begin{array}{l}\text { 1 to 2 series from 6 } 6 \\
\text { to } 10 \text { repetitions. }\end{array}$ & $\begin{array}{l}\text { Stretching; } \\
\text { breathing exercises; } \\
\text { The exercises. }\end{array}$ \\
\hline $3^{\text {rd }}$ & 40 & $\begin{array}{l}\text { Moderate; } \\
\text { Exercises with the help of balls, } \\
\text { roller pins and rubber bands. }\end{array}$ & $\begin{array}{l}\text { Alongamento; } \\
\text { Stretching; } \\
\text { breathing exercises; } \\
\text { The exercises. }\end{array}$ \\
\hline
\end{tabular}

Figure 1 - Timeline of Mat Pilates exercises

In all sessions, the principles of the Pilates method were applied: breathing with the activation of the multifidus and transversus abdominis muscles, and exercises did not follow a fixed and orderly sequence. In class, the exercises were as follows: the Spine Stretch Forward exercise, which aims at mobilizing the spine and stretch the posterior muscle chain; exercise Rolling Like a Ball, which strengthens the abdominal muscles (rectus abdominis, external oblique) and mobilizes the spine, Swan exercise, which lengthens the previous muscular chain of the trunk and mobilizes the spine; strengthens the pectoralis major muscle, brachial triceps, anterior deltoids and anconeus; Teaser exercise that aims at strengthening the rectus abdominis and external oblique; Saw exercise, which aims at stretching the muscles of the trunk rotators, hamstrings, lumbar square, strengthen the rectus abdominis, external oblique and internal abdomen; Shoulder Bridge, strengthens the anterior and posterior thigh muscles, buttocks and posterior muscles of the leg; Single Leg Stretch, strengthen the abdominal muscles, stretches the gluteus and lower back muscles; Criss Cross, strengthens the abdominal rectus muscle, external oblique and internal abdomen;
Leg Pull Front, strengthens the pectoralis major muscle, brachial triceps, anconeus, anterior deltoids, gluteus maximus, biceps femoris, semitendinosus and paraspinal; Roll-over, strengthening the external oblique muscle and rectus femoris; Swimming strengthens the paraspinal musculature, posterior and middle deltoid, gluteus maximus, biceps femoris, semitendinosus and semimembranosus; Side Plank, strengthens the stabilizing muscles of the spine; One Leg Circle, strengthens legs, stabilizes the pelvis, hip control, joint mobility, the posterior muscles stretch, stabilizes column; Hamstring Series (lying on the foam roller), strengthens and stretches the hamstrings, strengthens the adductors, proprioceptive training to control the trunk and lengthens longitudinal axis associated to the stabilization of the pelvis and hip dissociation.

Data were described by simple and cross frequency tables, average, standard deviation (SD) and coefficient of variation (CV). The difference between the initial and final measures to arm muscle area (AMA), was verified through Wilcoxon paired samples test (Wilcoxon Signed Rank Test).

The confidence level of $95.0 \%(\alpha=0.05)$ was 
considered. The data were analyzed using Statistical Analysis Software Program (version 9.0) from a database made using the spreadsheet program Microsoft Office Excel, 2013 version.

The study complied with the formal requirements contained in the national and international regulatory standards for research involving human beings.

\section{Results}

Of the 65 volunteers who began the Mat Pilates classes, 43 completed the intervention in 39 sessions. The average age was 71.23 (SD=6.22) years, average height of $1.55 \mathrm{~m}(\mathrm{SD}=0.07)$ and average body weight of 64.50 (SD=12.6) kg. The age variation coefficient was 8.73 , height 4.51 and 19.58 of the weight of older participants.

In Table 1, the distribution of the elderly can be verified, by age group and average arm muscle area before and after the Mat Pilates practice. It can be observed that the difference in the averages of the arm muscle area was statistically significant, before and after in both age groups. The highest average arm muscle area $\left(43.96 \mathrm{~cm}^{2}\right)$ was observed in the age group from 60 to 69 years after the intervention.

Concerning the measures of arm circumference and triceps skinfold thickness, before and after Mat Pilates practice, there was a significant increase $(p=0.0001)$ in the average $(30.51 \mathrm{~cm})$ of the circumference of the initial arm compared to the average $(31.44 \mathrm{~cm})$ of the circumference of the final arm as well as a significant decrease $(p<0.0001)$ of the initial average $(24.39 \mathrm{~mm})$ of triceps skinfold thickness in relation to the final average $(21.60 \mathrm{~mm})$.
Table 1 - Distribution of the elderly, according to average score of arm muscle area and age groups before after Mat Pilates practice

\begin{tabular}{|c|c|c|c|c|c|c|c|}
\hline \multirow{2}{*}{$\begin{array}{l}\text { Age } \\
\text { group }\end{array}$} & \multicolumn{3}{|c|}{ Before } & \multicolumn{3}{|c|}{ After } & \multirow{2}{*}{$\mathbf{p}^{*}$} \\
\hline & $\mathbf{n}$ & $\begin{array}{l}\text { Arm muscle } \\
\text { area }\left(\mathrm{cm}^{2}\right)\end{array}$ & $\begin{array}{l}\text { Average } \\
\text { score }\end{array}$ & $\mathbf{n}$ & $\begin{array}{l}\text { Arm muscle } \\
\text { area }\left(\mathrm{cm}^{2}\right)\end{array}$ & $\begin{array}{l}\text { Average } \\
\text { score }\end{array}$ & \\
\hline $60-69$ & 17 & 35.5 & 13.76 & 17 & 43.9 & 21.23 & 0.015 \\
\hline$\geq 70$ & 26 & 35.5 & 21.90 & 26 & 41.9 & 31.09 & 0.014 \\
\hline Total & 43 & 35.5 & 35.84 & 43 & 42.7 & 51.85 & 0.002 \\
\hline
\end{tabular}

The muscle mass of the elderly (Table 2 ), according to age groups before and after the intervention, showed that of the 43 elderly women, $53.5 \%$ had inadequate muscle mass before the intervention and $72.1 \%$ adequate muscle mass, after the intervention. This difference was statistically significant $(\mathrm{p}<0.002)$. The age group of the elderly older or equal to 70 years had the highest percentage of elderly with adequate muscle mass.

Table 2 - Distribution of elderly, according to the classification of muscle mass by age group, before and after Mat Pilates practice

\begin{tabular}{lcccc}
\hline & \multicolumn{2}{c}{ Before } & \multicolumn{2}{c}{ After } \\
\cline { 2 - 5 } $\begin{array}{l}\text { Age } \\
\text { group }\end{array}$ & $\begin{array}{c}\text { Inadequate } \\
\text { muscle mass } \\
\mathbf{n ( \% )}\end{array}$ & $\begin{array}{c}\text { Inadequate } \\
\text { muscle mass } \\
\mathbf{n}(\%)\end{array}$ & $\begin{array}{c}\text { Inadequate } \\
\text { muscle mass } \\
\mathbf{n}(\%)\end{array}$ & $\begin{array}{c}\text { Inadequate } \\
\text { muscle mass } \\
\mathbf{n}(\%)\end{array}$ \\
\hline $60-69$ & $10(23.2)$ & $7(16.2)$ & $6(13.9)$ & $11(25.5)$ \\
& $13(30.2)$ & $13(30.2)$ & $6(13.9)$ & $20(46.5)$ \\
Total & $23(53.5)$ & $20(46.5)$ & $12(27.9)$ & $31(72.1)$ \\
\hline
\end{tabular}




\section{Discussion}

Theoretically, the Mat Pilates method is not intended for hypertrophy, as seen in other methods that use load to recruit and increase the volume of muscle fibers. The method is described as complementary to the work of hypertrophy for the increase of muscle mass once the Mat Pilates exercises are more focused on the quality of motion than the number of repetitions performed ${ }^{(11-12)}$. Nevertheless, in this study, there was a significant increase $(\mathrm{p}<0.002)$ in muscle mass among the elderly compared the results before and after the Mat Pilates practice, indicating, therefore, increased muscle strength, even not using load, besides the weight of their own body. It is an important result, once that muscle mass is related to the reduction of risks to health, improvement and/ or maintenance of functional capacity and hence the quality of life of the elderly ${ }^{(4-6)}$.

Results related to the increase of lean body mass and decrease in body fat of the elderly, reversing some of the most serious consequences of aging associated with increased fat mass and reduced lean body mass, were found in another study regarding the effectiveness of a program of Mat Pilates exercises on body composition of the elderly women ${ }^{(15)}$. This method can significantly increase muscle mass and muscle strength, even not using load in addition to the body's own weight ${ }^{(12,16)}$. Nevertheless, the evaluation method of muscle mass and the training period used in these surveys are different, which makes the quantitative comparison with the present study difficult. Furthermore, other studies that specifically relate the practice of Mat Pilates to increase muscle mass in elderly women was not found in the literatures.

One possible scenario that perhaps justifies the results found may be the frequency or number of weekly sessions, three times a week, used in this study. In general, although the Mat Pilates method is much sought after by the elderly population, the majority ${ }^{(12-13)}$ of elderly subjects performing the activity once or twice a week, for reasons such as financial issues, climate and/or dependence to move around and attend the sports centers (they do not have a car, they do not drive). Another hypothesis to be considered is the period of three months, when the practice of Mat Pilates was performed, considering that the elderly increased muscle strength, mainly due to neural adaptations, and there is a greater intensity in the first six to eight weeks of training ${ }^{(17)}$. Thus, they suggest further research using the Mat Pilates with the same frequency, with the same period or longer and the same method of evaluation of the muscle mass for future comparisons.

In a systematic review study on the effects of the practice of the Mat Pilates method in elderly, it can be observed that the practice of the method was able to stabilize and even reverse some values of body composition during aging such as loss of muscle mass $^{(15)}$. The research mentioned in the review had the lowest score on the scale of assessment of the methodological quality among all studies evaluated, which questions the credibility of the study. In a study of young adults, in order to investigate the effects of body composition provided by the method, there was no change in the quantitative and qualitative measures in the body composition(16).

When comparing the Mat Pilates method, executed to methods using devices concerning electrical activation of active muscle groups, with 11 healthy women, showed that when compared to the same exercises (hundred teaser) performed both on the ground and with the device showed no differences in the activation of the rectus abdominis and rectus femoris $^{(18)}$.

Regarding the increase in arm circumference measurements $(p=0.0001)$ and decreased triceps skinfold thickness $(\mathrm{p}<0.0001)$, after Mat Pilates practice, the results showed and ratified the increase in muscle mass of the elderly with Mat Pilates practice, given that the increase in arm circumference was accompanied by decreased triceps skinfold thickness, a measure that, determines the fat mass. In other words, the arm circumference increased not due to 
the increase in fat mass, but the increase in lean body mass.

With regard to age groups, the elderly older than 70 years had a higher percentage $(46.5 \%)$ than the age group from 60 to 69 years $(25.5 \%)$ after the intervention.

Another study also showed favorable results in terms of respiratory muscle strength with the practice of Mat Pilates method in women aged 60 or older. After 11 weeks of practice, the effects of Mat Pilates exercises on respiratory muscle strength showed a significant increase in maximal expiratory pressure, the method is, therefore, one of the practices recommended to the elderly population ${ }^{(19)}$.

Since the number of people aged 60 and over grows in greater proportion than other age groups in the world population ${ }^{(2)}$, it is essential to know and understand the importance of muscle mass in reducing health risks, improvement and maintenance of the functional capacity and consequently the quality of life of the elderly ${ }^{(4-6)}$.

The World Health Organization recommends physical activities such as walking, dance classes, cycling, light jogging, swimming, aerobics and exercises planned in the context of family activity and the community, in addition to household chores, games and other adapted sports for adults over 60 years $^{(3,8,13)}$.

When considering the difficulties of exploratory and field research, the results are important and positive; however, the size of the group investigated should be highlighted. They suggest studies with larger groups and elderly of both sexes.

\section{Conclusion}

The Mat Pilates method increased muscle mass of most elderly participating in the study. This datum shows the importance of keeping active life even in old age, when the muscle mass is in sharp decline.

Another question and research focus is on the importance of Mat Pilates activity, even without extra load, the main characteristic concerning hypertrophy, is that it is effective in increasing muscle mass in older women, with exercises made with their own body weight.

\section{Collaborations}

Queiroz LCS, Bertolini SMMG, Bennemann RM and Silva ES contributed to the design, analysis, data interpretation, article writing, relevant critical review of the content and final approval of the version to be published.

\section{Referênces}

1. Instituto Brasileiro de Geografia e Estatística. Indicadores sócio demográficos prospectivos para o Brasil 1991-2030 [Internet]. 2012 [citado 2015 mar. 03]. Disponível em: http://www.ibge.gov.br/ home/estatistica/populacao/projeção

2. Souza SS. Desafios do envelhecimento populacional: como as legislações destinadas aos idosos têm ligado com essa nova demanda? Rev Interdiscipl Envelhec. 2015; 20(1):151-75.

3. Mota TMD, Souza CEAD. A influência do sedentarismo na prevalência da dor lombar: uma revisão de literatura. Interfisio [Internet]. 2013 [citado 2014 set. 01]. Disponível em: http:// interfisio.com.br/?artigo\&ID=489\&url=A-Influencia-do-Sedentarismo-na-Prevalencia-da-Dor-Lombar--Uma-Revisao-de-Literatura

4. Pícoli TS, Figueiredo LL, Patrizzi J. Sarcopenia e envelhecimento. Fisioter Mov. 2011; 24(3):45562.

5. Jentoft AJC, Landi F, Schneider SM, Zuniga C, Arai $\mathrm{H}$, Boirie $\mathrm{Y}$, et al . Prevalence of and interventions for sarcopenia in ageing adults: a systematic review. Report of the International Sarcopemia Initiative (EWGSOP and IWGS). Age Ageing. 2014; 43(6):748-59.

6. Daniel FNR, Vale RGS, Giani TS, Bacellar S, Dantas EHM. Functional autonomy of elderly women enrolled in a physical activity program. Acta Sci Health Sci. 2012; 34(3):151-6. 
7. Reis CB, Jesus RS, Silva OCS, Pinho L. Health conditions of young and old elderly. Rev Rene. 2016; 17(1):120-7.

8. Kamada M, Kitayuguchi J, Inoue S, Ishikawa $Y$, Nishiuchi H, Okada S, et al. A community-wide campaign to promote physical activity in middleaged and elderly people: a cluster randomized controlled trial. Int J Behav Nutr Phys Act [Internet]. 2013 [cited 2016 Mar. 13]; 10(44):216. Available from: http://ijbnpa.biomedcentral. com/articles/10.1186/1479-5868-10-44

9. Santos RG, Medeiros JC, Schmitt BD, Meneguci J, Santos DAT, Damião R, et al. Comportamento Sedentário em Idosos: uma revisão sistemática. Motricidade. 2015; 11(3):171-86.

10. Vaz RA, Liberali R, Cruz TMF, Netto MIA. Método pilates na melhora da flexibilidade - revisão sistemática. Rev Bras Prescr Fisiol Exercício. 2012; 6(31):25-31.

11. Conceição JS, Margener CR. Efficacy of ground Pilates for chronic low back pain patients. Case reports. Rev Dor. 2012; 13(4):385-8.

12. Merés G, Oliveira KB, Piazza MC, Preis C, Bertassoni Neto L. A importância da estabilização central no método pilates: uma revisão sistemática. Fisioter Mov. 2012; 2(2):445-51.

13. Bullo V, Bergamin M, Gobbo S, Sieverdes JC, Zaccaria M, Neunhaeusere D, et al. The effects of Pilates exercise training on physical fitness wellbeing in the elderly: A systematic review for future exercise prescription. Prev Med [Internet]. 2015 [cited 2016 Aug 07]; 75:1-11. Available from:http://www.sciencedirect.com/science/ article/pii/S0091743515000730
14. Barbosa RA, Souza JMP, Lebrão ML, Mrucci MFN. Relação entre estado nutricional e força de pressão manual em idosos do município de São Paulo, Brasil: dados da pesquisa Sabe. Rev Bras Cineantropom Desempenho Hum. 2006; 8(1):3744.

15. Engers PB, Rombaldi AJ, Portella EG, Silva MC. Efeitos da prática do método Pilates em idosos: uma revisão sistemática. Rev Bras Reumatol. 2015 [citado 2016 mai. 03]. Disponível em: http:// www.sciencedirect.com/science/article/pii/ S0482500416000449

16. Nogueira TRB, Oliveira GL, Oliveira TAP, Pagani MM, Silva JRV. Efeito do método pilates nas adaptações neuromusculares e na composição corporal de adultos jovens. Rev Bras Presc Fisiol Exercício. 2014; 8(45):296-303.

17. Dias CP, Toscan R, Camargo de M, Pereira EP, Griebler N, Baroni BM, et al. Effect of accentricfocused and conventional resistance training on strength and functional capacity of olde adults. Age (Dordr) [Internet]. 2015 [cited 2016 Jun 13]; 37(5):99. Available from: http://link.springer. com/article/10.1007\%2Fs11357-015-9838-1

18. Souza EF, Cantergi D, Mendonça A, Kennedy C, Loss JF. Análise eletromiográfica dos músculos reto femoral e reto abdominal durante aexecução dos exercícios hundred e teaser do método pilates. Rev Bras Med Esporte. 2012; 18(2):105-8.

19. Lopes EDS, Ruas G, Patrizzi LJ. Efeitos de exercícios do método pilates na força muscular respiratória de idosas: um ensaio clínico. Rev Bras Geriatr Gerontol. 2014; 17(3):517-23. 